\title{
ДИВЕРСИФІКАЦІЯ СІЛЬСЬКОГО ТУРИЗМУ В УКРАЇНІ НА ОСНОВІ ЄВРОПЕЙСЬКОГО ДОСВІДУ ${ }^{1}$ \\ DIVERSIFICATION OF RURAL TOURISM IN UKRAINE BASED ON THE EUROPEAN EXPERIENCE
}

\author{
Череп Олександр Григорович \\ доктор економічних наук, професор, \\ Запорізький національний університет \\ ORCID: https://orcid.org/0000-0002-3098-0105 \\ Осаул Аліна Олександрівна \\ старший викладач, \\ Запорізький національний університет \\ ORCID: https://orcid.org/0000-0001-8296-1123 \\ Cherep Olexandr, Osaul Alina \\ Zaporizhzhia National University
}

\begin{abstract}
Стаття присвячена нагальним питанням подальшого розвитку сільського туризму в Україні шляхом імплементування успішних європейських практик диверсифікації бізнесу. Наведено оцінку потенціалу сільського туризму. Проаналізовано наявні в природні рекреаційні ресурси, динаміку та структуру туристичних потоків, ступінь розвитку і готовності туристичної інфраструктури. Доведено, що ефективне використання туристичного потенціалу та визначення народногосподарської цінності туристичних ресурсів сприяє всебічному розвитку сільських територій. Зазначено, що диверсифікація діяльності є дієвим механізмом, який сприяє підвищенню зайнятості, зростанню доходів, роз язанню проблем концентрації робочої сили в містах та її браку в сільській місцевості. Продемонстровано доцільність використання європейського досвіду в процесі модернізації сільського туризму в Україні. За допомогою SWOT аналізу представлено сильні та слабкі сторони, можливості та загрози розвитку галузі сільського туризму в Україні.
\end{abstract}

Ключові слові: сільський туризм, диверсифікація, цінності, ресурси, зайнятість, доходи, туристичні потоки.

Статья посвящена актуальным вопросам дальнейшего развития сельского туризма в Украине путем внедрения успешных европейских практик диверсификации бизнеса. Приведена оценка потенциала сельского туризма. Проанализированы имеющиеся в стране природные рекреационные ресурсы, динамика и структура туристических потоков, степень развития и готовности туристической инфрраструктуры. Доказано, что эфффективное использование туристического потенциала и определение народнохозяйственной ценности туристических ресурсов способствуют всестороннему развитию сельских территорий. Отмечено, что диверсификация деятельности является действенным механизмом, который способствует повышению занятости, росту доходов, решению проблем концентрации рабочей силы в городах и ее нехватки в сельской местности. Продемонстрирована целесообразность использования европейского опыта в процессе модернизации сельского туризма в Украине. C помощью SWOT анализа представлены сильные и слабые стороны, возможности и угрозы развития сореры сельского туризма в Украине.

Ключевые слова: сельский туризм, диверсисикация, ценности, ресурсы, занятость, доходы, туристические потоки.

The article is devoted to topical issues of rural tourism further development in Ukraine by introducing successful European business diversification practices. The assessment of the capacity of rural tourism has been given. Natural recreational resources, dynamics and structure of tourist flows, development and tourism infrastructure

\footnotetext{
${ }^{1}$ Публікацію підготовлено в рамках проєкту «Диверсифікація сільського туризму через збалансованість та креативність: поширення європейського досвіду в Україні»/«Diversification of rural tourism through sustainability and creativity: disseminating European experience in Ukraine» (DIRUT) 620720-EPP-1-2020-1-UA-EPPJMO-MODULE за підтримки Програми Erasmus+: Jean Monnet Європейського Союзу, що реалізується у Запорізькому національному університеті (2020-2023).
} 
position have been analyzed. It has been proven that effective application of tourist potential and the evaluation of economic value of tourist resources contribute to the comprehensive development of rural areas. It has been noted that business ' diversification is an effective mechanism that contributes to higher employment rate, income growth, solving the problems of urban labour concentration and its lack in rural areas. It has been admitted that the European Union has a significant experience in implementation of the development and modernization programmes of rural tourism improvement, because they act as a determinant which promotes European regional development. Relevance of the European experience application in the process of rural tourism modernization in Ukraine has been demonstrated in the article. The authors have highlighted both strengths with opportunities, and weaknesses with threats of the field`s development in the nearest future. Since rural tourism economy is considered to be a comprehensive system, then changes observed in the countryside entail the need to adjust not only business strategies, but also the value orientations of its residents towards balanced and creative development as a source of spiritual values and cultural heritage. It has been figured out that the concept of authenticity must be taken into account when analyzing the quality of the new environment built in the field of agricultural tourism. Cultural heritage is a key point of the product authenticity. It has been proved that it is common practice among the EU member-countries who are looking for alternative ways of rural development to offer new directions for the development of the tourist industry through effective partnerships between countries, for example from Central and Eastern Europe.

Keywords: rural tourism, diversification, values, resources, employment, income, tourist flows.

Постановка проблеми. В 21 сторіччі сільський туризм як в усьому світі, так і в Україні, зазнає істотних змін та розглядається як джерело економічного зростання на макро- і мікроекономічному рівні, адже диверсифрікований дрібний та середній бізнес стає основним двигуном розвитку туристичної галузі. Сучасні прояви глобалізації, в тому числі пандемія COVID-19, світові тенденції щодо регулювання міграції населення, зміни в споживацьких настроях, транссрормація поглядів економічних суб єктів на роботу та відпочинок справляють істотний вплив на реалізацію потенціалу розвитку сільського туризму, спричиняють необхідність його диверсифрікації задля подальшого сталого розвитку. Сільський туризм традиційно представлений як стала, розгалужена діяльність у сільській місцевості на основі локальних ресурсів, сільського господарства, культурної спадщини та природного капіталу. Позитивний досвід імплементування сільського туризму в структуру національної економіки $€$ в багатьох країнах світу, в тому числі в країнах-членах ЄС. Україна знаходиться на шляху розбудови власної моделі розвитку сільського туризму, використовує досвід країн європейської спільноти, адаптує інструменти диверсифрікації діяльності задля подолання процесів депопуляції сільських територій, занепаду економіки, тощо. Використання новітніх видів діяльності, в тому числі неспоріднених із сільським господарством, накладається на тенденції переорієнтації масового міжнародного туризму на національний туристичний ринок, викликає необхідність розробки та впровадження нових норм підтримки та розвитку сільських територій як з боку національних урядів, так i місцевої влади, територіальних громад.

Аналіз останніх досліджень і публікацій. Можливості диверсифрікації економіки, створення міжгалузевих зв'язків, розвиток сільських територій у період пандемії $є$ предметом стратегій розвитку ЄС у цілому та окремих країн-учасниць, зокрема [1; 2]. Передумови та обґрунтування доцільності використання політики диверсифрікації в сфері сільського туризму, аналіз ринку та поведінки споживачів із метою підвищення конкурентоздатності бізнесу представлено в роботах як міжнародних експертів, наприклад, Міжнародної туристичної організації ООН [3], так і академічних дослідників [4]. Рекреаційні ресурси України є предметом дослідження Н.В. Фоменко [5] та С.Г. Ярьоменко [6]. У рамках проєкту USAID "Економічна підтримка Східної України" (ПроєкT USAID) розроблено документ «Колоритне Приазов'я: дорожня карта розвитку туризму. 2021-2030 роки» [7], який містить данні про туристичний потенціал регіону, стратегію розвитку туристичної сорери та систему управління дестинацією Приазов'я. Практика побудови бізнес моделей у сфері сільського туризму та відповідні випробувані бізнесмоделі з урахуванням політики диверсисрікації представлено в [8].

Виділення невирішеної раніше частини загальної проблеми. Розвиток сільського туризму та пропонування в рамках існуючих бізнес-підходів диверсифрікованих продуктів потребують подальшого вивчення з використанням напрацьованого світового досвіду, в тому числі європейського. Нові виклики навколишнього середовища, відсутність єдиного підходу щодо моделі розвитку сільських 
територій, часто-густо брак програм розвитку та дорожніх карт туристичних дестинацій у сільській місцевості, слабка політична воля та мінливе правове регулювання обумовлюють необхідність аналізу перспектив та можливостей диверсифрікації діяльності в галузі сільського туризму з метою стимулювання як сторони пропозиції, так і попиту.

Формулювання цілей статті. Метою статті $€$ розширення знань про практику диверсифрікації сільського туризму в Україні та аналіз європейських інструментів диверсисрікації, переваги та перешкоди їх застосування в Україні.

Виклад основного матеріалу дослідження. Україна має значний невикористаний туристично-рекреаційний потенціал для задоволення потреб туристів у послугах сільського туризму. Згідно даних Національної туристичної організації України «різноманітність культур, спадщини та екосистем в різних регіонах України є фоном для унікальних вражень відвідувачів, які не мають собі рівних ніде в світі» [9]. Досі більшу частину часу ринок сільського туризму України залишається ненасиченим. Однак, проведене в 2021 р. дослідження ринку туристичної галузі "Електоральні настрої. Щотижневий звіт" свідчить про пожвавлення ситуації, адже 53,1\% опитаних українців планують провести відпустку в Україні. «Серед них $17,4 \%$ запланували відпочинок в Одеській області, 11,8\% - у Закарпатській, 7,7\% у Запорізькій, 6,7\% - у Львівській, 6,2\% - у Херсонській. Найменше українців планують відпочивати в Севастополі - 0,1\%, в Автономній Республіці Крим - 0,4\%, у Тернопільській області - 0,8\%, у Луганській - 0,8\%» [10]. Потрібно зважати на те, що 23,7\% українців віком від 18-ти до «60+» років взагалі не подорожують, 21,6\% - раз на рік, 20,6\% - раз на кілька років і рідше, 12,4\% - раз на півтора року, 7,3\% - раз на місяць. Найбільш активними користувачем туристичних послуг в Україні є молодь віком від 18-ти до 24-х років, а саме 14,5\% молоді подорожує раз на місяць, 14,9\% - раз на кілька місяців, 20,6\% - раз на пів року. Лише 3,5\% молодих людей не подорожують взагалі [10]. Підсилення привабливості туристичних дестинацій, у тому числі на ринку сільського туризму, є можливим шляхом диверсифрікації туристичних послуг на засадах креативності та сталості. Така політика довела свою ефрективність та успішність в країнах Європейського союзу. Вона включає в себе екологічний, крафртовий, гастрономічний та розважально-культурний туризм, ство- рення SMART-комьюніті, креативних сільських хабів, проведення фестивалів місцевих народних промислів, тощо.

Європейський Союз має значний досвід розвитку та модернізації сільського туризму, адже він виступає чинником сприяння регіональному розвиткові в Європі. В Європейському Союзі існує розуміння того, що традиційне сільське господарство відіграє все меншу роль у більшості сільських територій. Це стосується показників зайнятості, ВВП та інших. У сучасному періоді сільський туризм розглядається урядами країн-членів ЄС як метод подолання безробіття та внутрішньої міграції, джерелом додаткових доходів. Вдосконалення механізмів ринкової економіки, адаптація країн до викликів останньої пандемії стали підґрунтям для розгляду сільського туризму в якості нової ринкової ніші. Уряди країн-членів $Є С$ впроваджують поступову реформу Спільної аграрної політики (CAР), яка окрім іншого передбачає субсидування розвитку села, ставить пріоритети щодо більш екологічно чистого виробництва, імплементування біовиробництва, а також розвитку сільського туризму. Орієнтація на диверсиорікацію сільської економіки означає, що підприємницька діяльність перетворюється на ефрективний засіб сприяння розвитку сільської економіки на засадах довгострокової стійкості. Скерована політика урядів $€ С$ визнає багатофункціональність сучасною ознакою сільського туризму, вбачає ії пріоритетом подальшого розвитку сільських територій. Відхід від вузького бачення диверсиорікації для потреб фрермерських господарств та зсув акцентів у бік сервісно-орієнтованого бізнесу окреслюють нові перспективи розвитку та нові обрії досягнення цілей сталого розвитку. Так як економіка сільського туризму $€$ цілісним явищем, то зміни, що спостерігаються на селі, тягнуть за собою необхідність переорієнтувати не тільки стратегії ведення бізнесу, але й ціннісні орієнтації його мешканців у бік відновлення, збалансованості та креативного розвитку життєвого сільського простору як джерела духовних цінностей та культурної спадщини.

Особлива увага, яка надається сільським територіям, передбачає комплексний підхід на рівні туристичних напрямків, а саме використання «інтегрованого менеджменту якості». Залучення всіх суб'єктів, які беруть участь у сільському туризмі, в тому числі операторів, туристів, професійних організацій, місцевих та національних органів влади, $€$ 
запорукою якості наданих послуг диверсифрікованого сільського туризму.

Важливим детермінантом якості нового середовища, побудованого в галузі сільського туризму $€ С$, виступає концепція автентичності. Автентичність $€$ визначальною для ідентисрікації конкурентної позиції продукту, а також його просування на ринку. Вона робить туристичний продукт унікальним, таким що відрізняється від інших наявних на ринку. Стрижнем автентичності продуктів сільського туризму виступає культурна спадщина, носіями якої $€$ місцеві мешканці розгалужених сільських територій.

Найбільш вдалі та найчастіше використовувані практики в сфрері диверсифікованого сільського туризму $є$ нерівномірно представленими в середині $€ C$, різняться між розвинутими та менш розвинутими членами. Тим не менш, помітним є прогрес країн Центральної та Східної Європи щодо використання практики диверсифікації розвитку сільського туризму, яка ґрунтується не тільки на культурній, але й на природній спадщині. Поєднання матеріальних та нематеріальних об'єктів спадщини, самоідентифрікація місцевого населення, його цінності, туристичні об єкти та місцева економіка в цілому стали базою для пересрорматування стратегій розвитку країн регіону, наріжним камінням їхнього інтегрування в загальноєвропейську економіку. Таким чином, країни ЄС шукають альтернативні шляхи розвитку сільських територій, пропонують нові напрямки розвитку туристичної індустрії. Ефрективними виявилися партнерства між країнами, наприклад Центральної та Східної Європи, що кореспондується 3 Програмою Європейської Комісії зі структурного фрінансування альянсів. Слід звернути увагу на те, що поглиблення диверсифікації індустрії туризму має не тільки національний, але й місцевий та регіональний вимір, адже загальне адміністрування програми розвитку сільських територій потребує нових інституційних фрорм та методів роботи, так званого «нового менеджменту в сільській місцевості», кооперативної діяльності громад, участі зацікавлених сторін в спільних заходах, у тому числі дорадництві.

Україна стикається 3 такими ж викликами, що стоять перед збалансованим сільським туризмом, як і країни ЄС. Нагальними $€$ питання збереження природних та культурних ресурсів; обмеження негативного антропогенного впливу на туристичні локації та природні ресурси через утворення відходів; сприяння добробуту місцевих громад; зменшення чиннику сезонності попиту; обмеження впливу транспорту, пов'язаного з туризмом, на навколишнє середовище; розробки концепції туризму доступного для всіх; створення та підвищення якості робочих місць у сорері сільського туризму. 3 огляду на це Кабінет Міністрів України розробив законопроєкт, необхідний для розвитку сільського туризму в Україні, який містить «питання розвитку ссрери послуг сільського туризму і визначає загальні правові, організаційні та соціальноекономічні засади діяльності працівників цієї сорери» [11]. В березні 2021 р. президентом України В. Зеленським було анонсовано Програму президента «Нове село», спрямовану на системний розвиток соціальної інфрраструктури, а саме ЦНАП, відділень пошти, аптек, опорних пунктів поліції, магазинів та медичних центрів [12]. Основою розвитку ініціативи має стати малий та середній бізнес за підтримки місцевої влади та Фонду розвитку сільських територій. Будівництво в сільській місцевості «Центрів тяжіння» має стати основою для розвитку сільського туризму. Вдосконалені сервісні зони розглядатимуться як чинник тяжіння туристів різних вікових груп та доходів.

Серед особливостей подальшого розвитку диверсифікованого сільського туризму доцільно виділяти економічні, соціокультурні, екологічні та інституційні сильні та слабкі сторони. До сильних сторін слід віднести популяризацію сільського туризму як у країні в цілому, так і на регіональному рівні; прибутковість бізнесу в сорері сільського туризму; розбудову та ефективне фрункціонування ринку основної сільськогосподарської продукції та похідних продуктів для туристів; високу схильність до інвестицій у галузі диверсифікованого сільського туризму та поетапне планування діяльності з метою всеохоплюючого використання наявних природних та людських ресурсів, культурної спадщини; релевантні знання та освіту, а також схильність до соціальної взаємодії заради досягнення спільної мети розвитку диверсифрікованого сільського туризму; традиції, місцеву культуру та мальовничі види; близькість до урбаністичних центрів, привабливі кліматичні умови та ландшасрти; зайнятість місцевого населення в галузі сільського туризму як запорука розвитку локальної інфрраструктури. Разом сильні сторони утворюють підстави для розгляду потенційних можливостей розвитку сектору сільського туризму в Україні, а саме 
зростання урядового інтересу до державного планування діяльності та фрінансового стимулювання розвитку; підсилення приватних ініціатив; доступності послуг диверсифрікованого сільського туризму для міського населення; підтримки інституцій у ссрері туризму, в тому числі неурядових; збільшення мотивування різних верств населення у послугах диверсисрікованого сільського туризму як внутрішнього, так і міжнародного; позитивної тенденції участі в міжнародних проєктах із розвитку туристичного потенціалу сільських територій, а також підвищення квалісрікації, отримання необхідних навичок та знань; подолання проблем злиденності та бідності.

До слабких сторін розвитку диверсифікованого сільського туризму в Україні можна віднести брак стратегічного бачення на державному та місцевому рівнях планування та фрінансування розвитку сільських територій; слабку мотивацію суб єктів господарювання до інвестування в об єкти сільського туризму; нерелевантний сучасним вимогам житловий оронд; нерівномірний туристичний потік продовж туристичного року; брак кваліфрікованої та досвідченої робочої сили в сільській місцевості, яка спеціалізується на сільському туризмі; неадекватний рівень інсрраструктури, в тому числі транспортно-експлуатаційного стану доріг; застаріле або відсутнє обладнання в ссрері сільської рекреації та спорту; нерозвинуту систему брендінгу продуктів сільського туризму та маркетингових каналів поставок; низький рівень диверсифрікації продуктів сільського туризму; слабку обізнаність потенційних сільських туристів про можливості активного та пасивного відпочинку; низький рівень взаємодії між суб`єктами господарської діяльності в галузі диверсифрікованого сільського туризму. В цілому слабкі сторони формують підстави формулювання загроз подальшого розвитку галузі, в тому числі йдеться про нестабільну політичну та економічну ситуацію; бюрократичні та фрінансові перешкоди організації та ведення бізнесу; скорочення або цілковиту втрату територій придатних для надання послуг сільського диверсифікованого туризму; втрату культурної спадщини.

Висновки. Наразі розвиток туристичного ринку знаходиться під впливом пандемії Covid-19, що дає підстави для переформатування традиційних маршрутів та скерування доходів зі світового на внутрішній національний ринок. Актуальними стають реформи в політиці розвитку сільських територій на національному, регіональному та місцевому рівнях, особливо з огляду на нові загрози та виклики, соціально-економічні проблеми, з якими стикаються всі ринкові гравці. Серед перспективних напрямків діяльності у сорері туризму $\epsilon$ сільський туризм. Зміни у поведінці туристів, їх смаках та вподобаннях визначають тенденції розвитку сільського туризму. Зміщення пріоритетів розвитку на рівень окремої громади потребує відповідної державної політики, що ставить за мету не тільки регулювання розвитку сільських районів, але й реалізацію їхнього потенціалу. Сільський туризм повинен розглядатися як засіб вирішення соціальноекономічних проблем місцевих громад, особливо тих, що стикаються із падінням привабливості традиційних сільськогосподарських видів діяльності. Переваги сільського туризму визначаються його потенціалом в створенні нових робочих місць та додаткових доходів для мікропідприємств, малого та середнього бізнесу. Розвиток сільського туризму ґрунтується на збереженні ресурсного потенціалу територій та забезпеченні належних умов життя їхніх мешканців, сільської інсрраструктури, охорони та збереження культурної та природної спадщини. Окрім того, фрормування нового бачення розвитку сільського туризму через призму його диверсифрікації повинно базуватися на маркетинговому підході до внутрішнього та зовнішнього середовища сільського туризму, сильних та слабких сторонах його розвитку, виявленні загроз та використанні потенційних можливостей.

\section{СПИСОК ВИКОРИСТАНИХ ДЖЕРЕЛ:}

1.OECD: Tourism Policy Responses to the coronavirus (COVID-19). June 2020. URL: https://www.oecd.org/ coronavirus/policy-responses/tourism-policy-responses-to-the-coronavirus-covid-19-6466аa20/ (дата звернення: 15.06.2021).

2. Department of Rural and Community Development: Our Rural Future. Rural Development Policy 2021-2025. March 2021. URL: https://www.gov.ie/en/publication/4c236-our-rural-future-vision-and-policy-context/ (дата звернення: 10.06.2021).

3. UNWTO: COVID-19 and tourism. 2020: A year in review. January 2021. URL: https://www.unwto.org/covid-19and-tourism-2020 (дата звернення: 20.06.2021). 
4. Marques Santos A., Madrid González C., Haegeman K., Rainoldi A. Behavioural changes in tourism in times of COVID-19. Employment scenarios and policy options. 2020. URL: https://s3platform.jrc.ec.europa.eu/ documents/20182/392265/Behavioural+changes+in+tourism+in+times+of+COVID-19/059ea958-6696-467a8507-2е8617a4b86a (дата звернення: 01.07.2021).

5. Фоменко Н.В. Рекреаційні ресурси та курортологія. Київ : Центр навчальної літератури, 2007. 312 с.

6. Ярьоменко С.Г. Туристичні ресурси України : навч. посіб. ОЛДІ-ПЛЮС, 2021. 472 с.

7. Лієв О. Колоритне Приазов'я: дорожня карта розвитку туризму. 2021-2030 роки. 2021. 196 с.

8. Living lab research concept in rural areas. URL: https://cordis.europa.eu/project/id/773757 (дата звернення: 02.07.2021).

9. НTOУ Про сільський туризм. URL: http://www.ntoukraine.org/year2020_ua.html (дата звернення: 01.07.2021).

10. Дослідження ринку туристичної галузі: «Електоральні настрої. Щотижневий звіт». Укрінфрорм. URL: https://www.ukrinform.ua/rubric-presshall/3253767-doslidzenna-rinku-turisticnoi-galuzi-elektoralni-nastroi-soti znevij-zvit.html (дата звернення: 10.07.2021).

11. Кабмин разработал законопроект о развитии сельского туризма. Бизнес Цензор. 2021. 16 черBH. URL: https://biz.censor.net/news/3271650/kabmin_razrabotal_zakonoproekt_o_razvitii_selskogo_turizma (дата звернення: 28.06.2021).

12. Мінрегіон: програма "Нове село" передбачає будівництво у сільській місцевості сучасних просторів. Міністерство розвитку громад та територій України. Офріційний веб-сайт Miнiстерства. URL https://www.minregion.gov.ua/press/news/minregion-programa-nove-selo-peredbachaye-budivnycztvo-u-silskijmisczevosti-suchasnyh-prostoriv/ (дата звернення: 28.06.2021).

\section{REFERENCES:}

1. OECD: Tourism Policy Responses to the coronavirus (COVID-19). June 2020. Available at: https://www.oecd.org/ coronavirus/policy-responses/tourism-policy-responses-to-coronavirus-covid-19-6466aa20/ (accessed 15 June 2021 ).

2. Department of Rural and Community Development: Our Rural Future. Rural Development Policy 2021-2025. March 2021. Available at: https://www.gov.ie/en/publication/4c236-our-rural-future-vision-and-policy-context/ (accessed 10 June 2021).

3. UNWTO: COVID-19 and tourism. 2020: A year in review. January 2021. Available at: https://www.unwto.org/ covid-19-and-tourism-2020 (accessed 20 June 2021).

4. Marques Santos A., Madrid González C., Haegeman K., Rainoldi A. (2020) Behavioural changes in tourism in times of COVID-19. Employment scenarios and policy options. Available at: https://s3platform.jrc.ec.europa.eu/ documents/20182/392265/Behavioural+changes+in+tourism+in+times+of+COVID-19/059ea958-6696-467a8507-2e8617a4b86a (accessed 01 July 2021).

5. Fomenko N.V. (2007) Rekreatsiini resursy ta kurortolohiia [Recreational resources and resortology]. Kyiv: Tsentr navchalnoi literatury. 312 p. (in Ukrainian)

6. Yaromenko S.H. (2021) Turystychni resursy Ukrainy: navchalnyi posibnyk [Tourist resources of Ukrain: textbook]. OLDI-PLIUS. 472 p. (in Ukrainian)

7. Liiev O. (2021) Kolorytne Pryazovia: dorozhnia karta rozvytku turyzmu. 2021-2030 roky [Colorful Azov: Road Map of Tourism Development. 2021 - 2030 s.]. 196 p. (in Ukrainian)

8. Living lab research concept in rural areas. Available at: https://cordis.europa.eu/project/id/773757 (accessed 02 July 2021).

9. NTOU Pro silskyi turyzm [NTOU About rural tourism]. Available at: http://www.ntoukraine.org/year2020_ua.html (accessed 10 July 2021).

10. Doslidzhennia rynku turystychnoi haluzi: "Elektoralni nastroi. Shchotyzhnevyi zvit" [Tourism market research: "Electoral sentiment. Weekly report"]. Ukrinform. Available at: https://www.ukrinform.ua/rubric-presshall/3253767doslidzenna-rinku-turisticnoi-galuzi-elektoralni-nastroi-sotiznevij-zvit.html (accessed 28 June 2021).

11. Kabmyn razrabotal zakonoproekt o razvytyy selskoho turyzma (2021) [The Cabinet of Ministers has developed a bill on the development of rural tourism]. Byznes Tsenzor. Available at: https://biz.censor.net/news/3271650/ kabmin_razrabotal_zakonoproekt_o_razvitii_selskogo_turizma (accessed 28 June 2021).

12. Minrehion: prohrama "Nove selo" peredbachaie budivnytstvo u silskii mistsevosti suchasnykh prostoriv. Ministerstvo rozvytku hromad ta terytorii Ukrainy. Ofitsiinyi veb-sait Ministerstva [Ministry of the Regional Development: the New Village program envisages the construction of modern spaces in rural areas. Ministry of the Development of Communities and Territories of Ukraine. Official website of the Ministry]. Available at: https://www.minregion.gov.ua/ press/news/minregion-programa-nove-selo-peredbachaye-budivnycztvo-u-silskij-misczevosti-suchasnyh-prostoriv/ (accessed 28 June 2021). 